\title{
Maintenance costs estimation for a mid-tier Shipyard
}

DOI: https://doi.org/10.25043/19098642.198

Miguel Calvache Ramírez ${ }^{1}$

Andrés Eloy García Barón ${ }^{2}$

\begin{abstract}
This document presents a detailed shipyard maintenance cost analysis. The first step was to gather information on some industries maintenance studies, to estimate the adequate maintenance budget for a medium size shipyard. A methodology to calculate the approximate maintenance budget is proposed, through a benchmarking of recommended maintenance costs.
\end{abstract}

Key words: Shipyard, maintenance cost, maintenance, costs methodology.

\section{Resumen}

Este documento presenta un análisis detallado de los costos de mantenimiento del astillero. El primer paso fue reunir información sobre los estudios de mantenimiento de algunas industrias, para estimar el presupuesto de mantenimiento adecuado para un astillero de tamańo mediano. Se propone una metodología para calcular el presupuesto de mantenimiento aproximado, a través de una evaluación comparativa de los costos de mantenimiento recomendados.

Palabras claves: Astillero, costo de mantenimiento, mantenimiento, metodología de costos.

Date Received: December 1st 2019 - Fecha de recepción: Diciembre 1 de 2019

Date Accepted: January 30 2020 - Fecha de aceptación: Enero 30 de 2020

\footnotetext{
${ }^{1}$ COTECMAR. Cartagena, Colombia. Email: mcalvache@cotecmar.com

${ }^{2}$ COTECMAR. Cartagena, Colombia. Email: eloygarcia08@hotmail.com
} 


\section{Objective}

Estimate the annual cost of the medium shipyard building plant maintenance, as a rule of thumb, with few information available in order to get an approximate and preliminary value.

\section{Introduction}

In Colombia, industries have a great challenge to estimate maintenance costs and its effectiveness. Although, there's different authors that propose different methods to calculate maintenance budget, it is not known which should be the ideal or adequate quantity to obtain the greatest Return On Assets (ROA) whit the lower maintenance cost, in a general manner. What does exist is historical data series that put in evidence the evolution of maintenance since its beginning until present [1].

Currently, many companies in developing countries tend to invest great amounts in technological advancement, innovation, plant staff training and process improvement. Nevertheless, inside this organization chart it is common to find that these companies exclude very relevant areas to maintain the company, as it is maintenance itself [2].

Despite global advancement over maintenance, as the instrumentation technology implementation, the automation software development and the strict maintenance plans creation, in Colombia only a few companies invest the right amount on it. According to Patińo [3] one of the greatest limitations is that companies do not have access to maintenance information systems in general and there is not an specific organization chart that could be suited to any company. In the same way it concludes that for this reason each company seems to be forced to create its own department, which will be in charge to bring technical support to the plant.

Another aspect that limits the maintenance management is the corporative assets control, which is the biggest obstacle that Colombian companies face. The result of a survey made by ACIEM $^{1}$ to 410 companies in Colombia, shows that $64 \%$ of these industries manages the maintenance information manually or through a third party, making this task more strenuous and inefficient in decision making [2].

There is 3 principal maintenance kinds [4]: corrective, preventive and predictive, also evolved as RCM (reliability-centered maintenance). Among those, our country focuses in a single one: Corrective maintenance, or "reactive" [3]. This maintenance is performed when affected equipment gets repaired and bring it to its normal operation state. This methodology results more expensive at the end, if we count the consequences of equipment stops and the repair itself.

Preventive maintenance is performed before the failure occurs. Programmed stops are performed according to a maintenance plan previously assigned for the equipment. Worn parts get replaced, lubrication and inspection, among other practices to avoid big corrective maintenance costs is performed.

Luisa Patiño [3, p. 29] affirms that the metalworking industry is implementing new technologies and machines that in most cases are expensive. This has been confirmed in the last industry fairs [5]. This state of the art machinery is being acquired by shipyards, for that reason preventive maintenance is necessary to protect this costly equipment.

Predictive maintenance: for this, exhaustive equipment monitoring is performed to know the current status and in this way draft a timely maintenance plan. The RCM integrates Preventive Maintenance (PM), PredictiveTesting and Inspection (PT\&I), Repair (also called reactive maintenance), and Proactive Maintenance to increase the probability that a machine or component will function in the required manner over its design life-cycle with a minimum amount of maintenance and downtime [6]. Although is and old concept of the 80 's, still its apllication is made mainly by the aeronautical, spacecraft, nuclear indusries and the $\mathrm{DoD}$. The problem of this kind of maintenance is

\footnotetext{
ACIEM: Asociación Colombiana de ingenieros.
} 
that trained personnel and specialized tools that are required, which increases the initial cost. For this reason, predictive maintenance is still scarce in the Colombian industries.

\section{Approximate Maintenance Annual Budget in Colombian Companies}

According to ACIEM report [2, p. 41] concludes:

1. Colombian companies expend $22.5 \%$ of their annual budget in their plant maintenance, which gets close to the best maintenance practices where companies invest $20 \%$.

2. In average, the Colombian industries invest $12 \%$ of the value of their assets; In particular, this percentage is different for each company according to its size:

- Micro company $13 \%$.

- Small and medium company $8 \%$.

- Big company $11 \%$.

\section{How maintenance cost is estimated?}

Based on the methodology proposed by Juan Díaz Navarro in his book "Técnicas del Mantenimiento Industrial" [7] the next costs structure arises:
1. “... each kind of company will require an adequate maintenance service to their production, but not separated from it on any case..." [8]. Quoting the previous sentence, the maintenance activity is started agreeing with the production department, certain strategic parameters to not lose time in unsuccessful debates. Such parameters are:

- What is expected from the maintenance service?

- What way is needed to perform such maintenance labours?

- How performance will be measured?

- How will maintenance activities be controlled and followed in the plant?

- What is the annual production program in the plant.

2. The assets will be classified in the next category groups:

FIE: Fixed and Infrastructure Equipment (Pipes, Superstructure, tanks).

EME: Electrical and Mechanical Equipment (welding machines, polishers, combustion engines).

Then proceed to find the maintenance budget following the next structure:

Fig. 1. Maintenance Cost Organization Chart. Source: [7, p. 51]. Edited by the author.

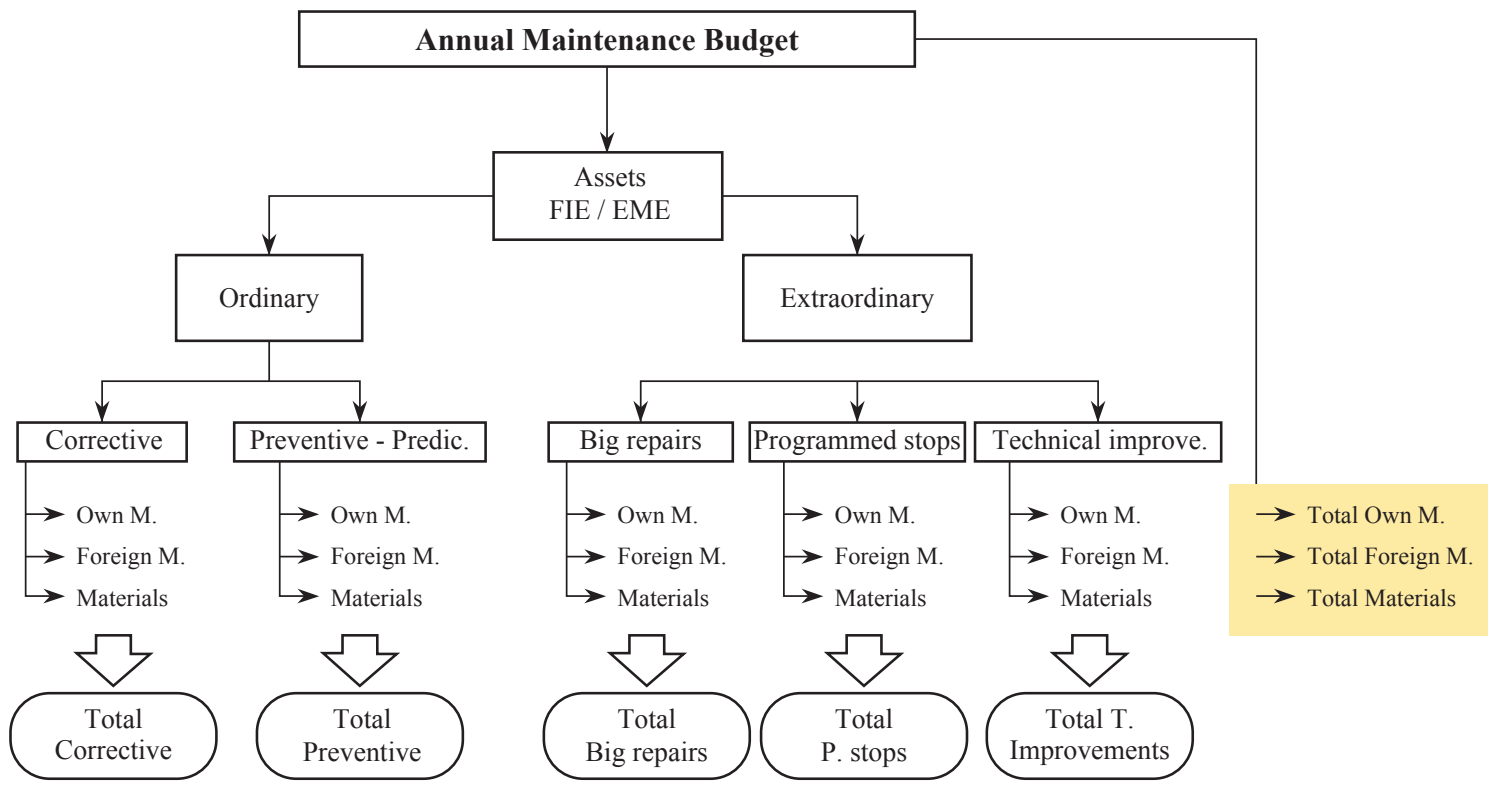


The own maintenance cost can be found as follows:

Maintenance staff hours multiplied by its own cost. The maintenance hour in each specialty is conformed by:

- Operating work force (salaries plus social tax charges).

- Maintenance supervisor and management or intermediary personnel.

- Another maintenance expenses:

- Water, steam, power.

- Training, management.

- Maintenance installations and workshops (this is omitted if is worked inside the same plant to simplify the operation).

- Non distributed materials, job specific.

- Tools.

- Measurement instruments.

- Supplies and minor materials.

The maintenance cost per hour in Colombian pesos $(\mathrm{COP} / \mathrm{h})$ is made adding these 4 costs and dividing them by the maintenance performed hours.

According to Diaz. J [7], the previously proposed belong to the maintenance direct costs; nevertheless, could be far from its real cost. To improve this calculation, maintenance indirect costs must be included, that could at the end be higher than the direct costs if they are not checked and controlled in detail. These indirect costs are related to:

- Production cost loss by equipment stop.

- Penalties on delivery delays.

- Extra hours due to low equipment productivity.

- Negative effects on personnel and environmental safety.

- External equipment rentals due to own equipment failures.

On this idea, the total maintenance cost is given by the direct plus indirect maintenance costs, this is known as the integral cost.

On the other hand, we must keep in mind that is not always recommended to make maintenance to an equipment. In some cases, this is not profitable, and it has to be with the machine's life cycle. On this same way, Diaz proposes that the life cycle cost is given by:

$$
C=A+F+M+r
$$

Where

$A$ is the purchasing cost.

$F$ is the working cost (raw materials, energy, etc.)

$M$ is the maintenance cost.

$r$ is the residual value (if it has any).

Being $I$ the generated income by the equipment, the profit is given by:

$$
\begin{aligned}
& R=I-C \\
& R=I-C(A+F+M+r)
\end{aligned}
$$

If $R<0$ it means that the equipment is generating losses to the company.

If $R>0$ it means that the equipment is generating profits to the company.

Ignoring the value of $r$, the prior equation can be represented in the next graph:

Fig. 2. Maintenance Effectiveness.

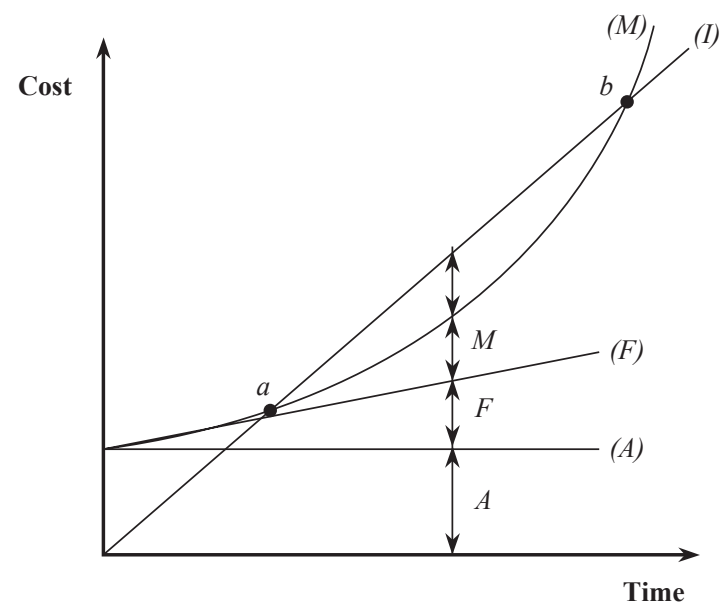

Source: (Navarro,2007).

Where $R$ is positive between $a$ and $b$.

Before to reach the investment return point (a), the operation is non profitable because the spending is larger than the income, due to the purchasing cost. 
From (b) the same problem shows, given that the maintenance costs exponentially increase, because most of the parts will be very worn or it will have an old technology.

Finally, to find an equipment failure periodicity, a yearly average for each kind of failure is estimated and the time of the year in which the failure happens.

All these variables used to find the maintenance cost, could vary so much that makes this estimation a real challenge. As Komonen [9] mentioned, the maintenance cost can vary from $0.5 \%$ to $25 \%$ in a study made on companies in Finland. Nevertheless, in the Spanish companies that uncertainty has being reduced and is evident the improvement in the maintenance practices, that bring as a result the decrease in associated costs over the years [10]. This improvement tendency on Spanish companies is shown in Fig. 3.

In that same way, the distribution of maintenance in Spanish companies is presented in Fig. 4, assuming that the total maintenance is $100 \%$ and is divided between preventive and corrective maintenance. The percentage of preventive maintenance is shown. The corrective maintenance is the complement.
From Fig. 4 we could conclude that more than $70 \%$ of Spanish companies have more than $50 \%$ corrective maintenance [10]. Is evident then, that there's an inclination on this companies to distribute maintenance as: $30 \%$ to $40 \%$ preventive and $60 \%$ to $70 \%$ corrective.

Is important that companies have clear towards what kind of maintenance aim. Garcia [11] explains in his blog, the focuses of the maintenance over the years:

There are 5 maintenance generations, being consequently one better than the previous one. The first generation perform corrective maintenance. In the second the term "preventive maintenance" arises, this is shown by a higher demand in production continuity. The third generation is focused in equipment availability, so it gives birth to predictive maintenance. The fourth generation integrate all the prior knowledge, adding the customer expectations. The fifth generation is focused in the systems energy efficiency.

\section{Maintenance cost rule-of-thumb}

As shown before, a detailed analysis and cost estimation must include many facts and values to

Fig. 3. Maintenance Effectiveness Evolution in Spain Companies.

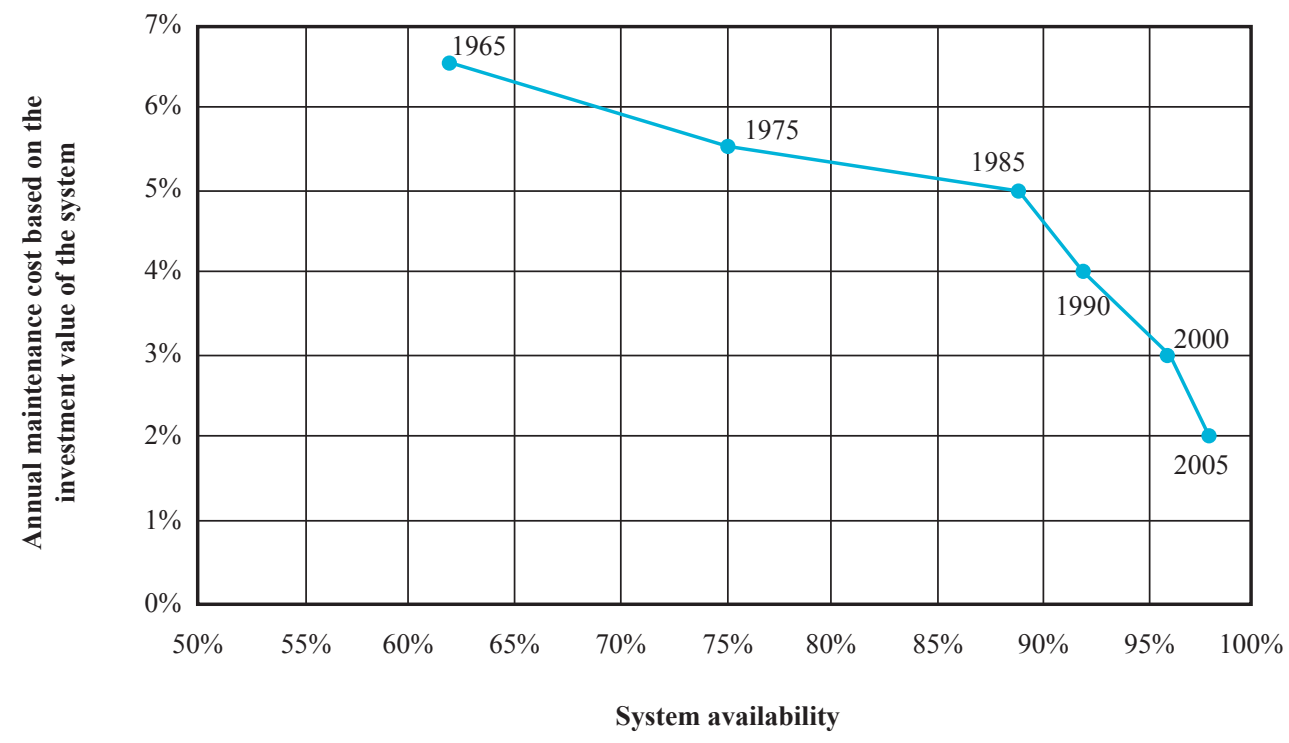

Source: [10] 
Fig. 4. Preventive Maintenance Distribution against corrective in Spanish Companies.

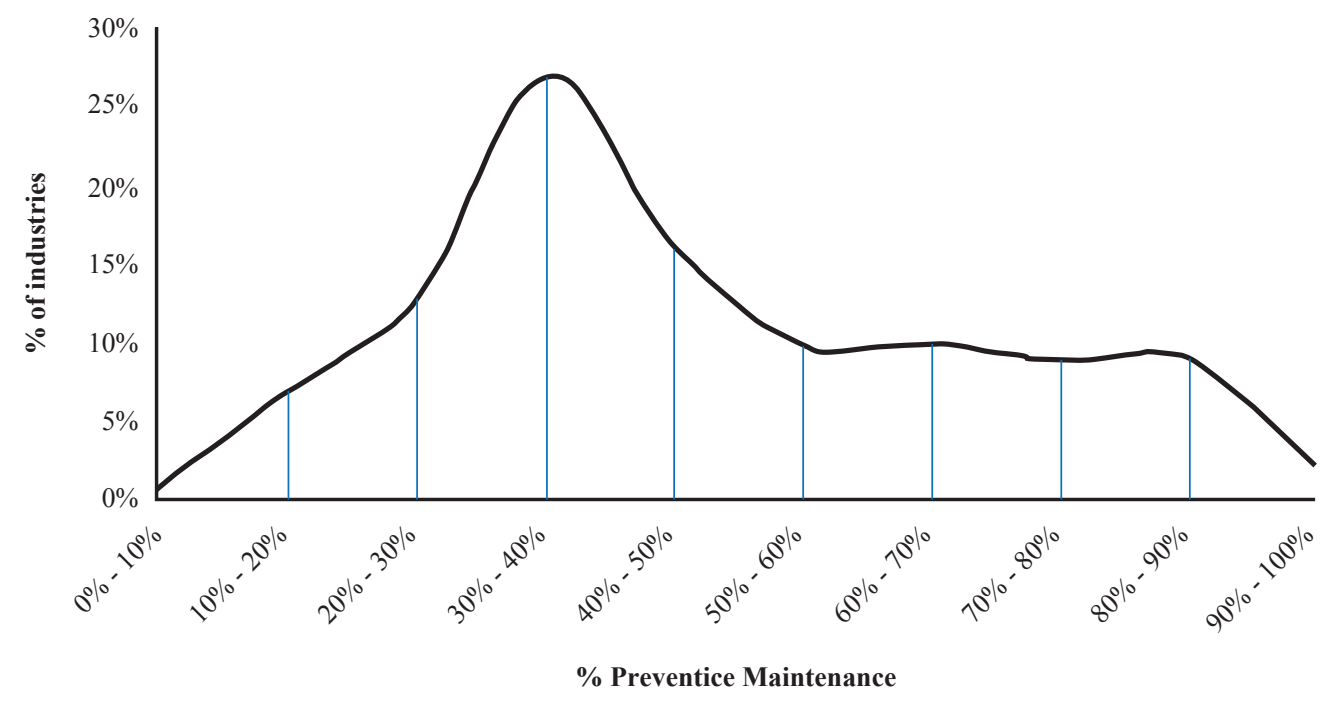

Source: [10]

get a exact amount for the annual maintenance budget. However, most of this information is not know or very difficult to get, not to say the amount of time (and so money) that it would require. This is why is important to have an approximate amount to start a budget, and then make it more specific for each company or shipyard.
For this purpose, many literature and sources were consulted, in order to get a general percentage that should be expended in maintenance, regarding the acquisition value of the assets. In Fig. 5 is shown the maintenance cost of some industrial equipment and transportation means. The horizontal axis is in logarithmic scale.

Fig. 5. Companies Maintenance Cost.

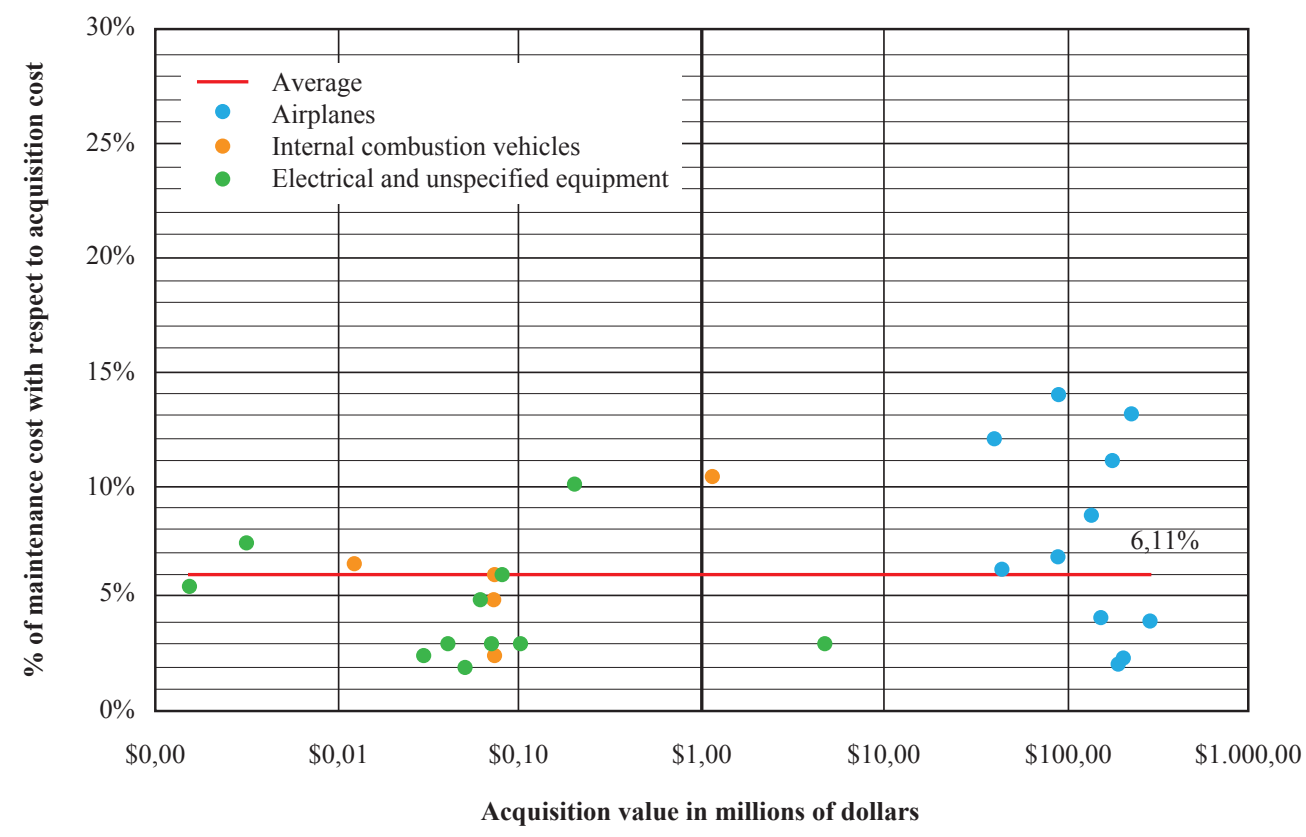

Source: The author based this on researched information. See Table 1. 
Table 1. Industries Maintenance Cost.

\begin{tabular}{|c|c|c|c|c|}
\hline $\begin{array}{l}\text { Machinery/ } \\
\text { Infrastructure }\end{array}$ & Category & Asset Type & $\begin{array}{l}\text { Maintenance Value } \\
\text { (\% acquisition value) }\end{array}$ & Source \\
\hline \multirow{13}{*}{ Machinery } & \multirow{8}{*}{$\begin{array}{l}\text { Electrical } \\
\text { Equipment and } \\
\text { non specific }\end{array}$} & Pumps & $15 \%$ & {$[12$, p. 117$]$} \\
\hline & & Non Specific & $3-6 \%$ & {$[12$, p. 49$]$} \\
\hline & & Non Specific & $3-5 \%$ & {$[2$, p. 42$]$} \\
\hline & & Electric Locomotive & $3.08 \%$ & {$[13]$} \\
\hline & & Compressors & $7.4 \%$ & {$[14]$} \\
\hline & & Non Specific & $2-3 \%$ & {$[15$} \\
\hline & & Conventional Lathe & $5.5 \%$ & {$[16]$} \\
\hline & & Non Specific & $2.05-10 \%$ & {$[9]$} \\
\hline & \multirow{5}{*}{$\begin{array}{l}\text { Internal } \\
\text { Combustion } \\
\text { Equipment }\end{array}$} & Fighter planes & $6.41 \%-10.79 \%$ & {$[17]$} \\
\hline & & $\begin{array}{l}\text { ICV (Internal combustion } \\
\text { vehicle) }\end{array}$ & $6.54 \%$ & {$[18]$} \\
\hline & & Lift Truck & $2.4 \%, 4.99 \%, 6.01 \%$ & {$[19]$} \\
\hline & & Machinery & $11 \%$ & {$[2]$} \\
\hline & & Tipper Trucks & $10.4 \%$ & {$[4][20]$} \\
\hline \multirow{2}{*}{ Infrastructure } & \multirow{2}{*}{ Static Equipment } & Railways & $1.52-2.11 \%$ & {$[21][22]$} \\
\hline & & Pipelines & $0.2 \%$ & {$[23]$} \\
\hline
\end{tabular}

Source: Author, with different sources data.

According to Fig. 5 is estimated that industries invest in machinery maintenance an annual average of $6.11 \%$ of their assets value. For infrastructure there is an average of $1.27 \%$.

\section{Mid-Tier Shipyard}

A shipyard is an industrial factory aimed to build and repair vessels, and it is a labor intense type. It includes the intensive use of mechanical and electrical tools, big size facilities, shops and hangars.

As an example, we will consider an generic and imaginary mid-tier shipyard, in order to calculate how big should be is annual budget for maintenance. We consider a general asset distribution as the presented in Table 1.
Table 2. Acquisition value of the assets Mid-Tier Shipyard [USD].

\begin{tabular}{lr}
\hline \multicolumn{1}{c}{ Asset Type } & \multicolumn{1}{c}{ Present Value } \\
\hline Infraestructure - buildings & $\$ 4.300 .000$ \\
\hline Equipment - Machinery & $\$ 1.900 .000$ \\
\hline Manual tools & $\$ 1.100 .000$ \\
\hline General Total: & $\$ \mathbf{7 . 3 0 0 . 0 0 0}$ \\
\hline
\end{tabular}

Considering these values, we apply the gotten percentages estimated for maintenance, and get the approximate annual maintenance cost. This calculation is made to get the approximate percentage of the acquisition cost that should be invested yearly to maintain the company assets. 
Table 3. Projected maintenance annual cost.

\begin{tabular}{|c|c|c|c|c|}
\hline & \multicolumn{2}{|c|}{ Assets value } & \multicolumn{2}{|c|}{$\begin{array}{c}\text { Annual } \\
\text { maintenance cost }\end{array}$} \\
\hline & [M USD] & {$[\%]$} & {$[\%]$} & [USD] \\
\hline $\begin{array}{l}\text { Infraestructure - } \\
\text { buildings }\end{array}$ & 4.3 & 59 & 1.27 & 54.610 \\
\hline $\begin{array}{l}\text { Equipment - } \\
\text { Machinery }\end{array}$ & 1.9 & 26 & 6.11 & 116.090 \\
\hline Manual tools & 1.1 & 15 & 6.11 & 67.210 \\
\hline Total & 7.3 & 100 & 3.26 & 237.910 \\
\hline
\end{tabular}

As a result, the annual maintenance cost of this virtual shipyard is around $\$ 238.000$ and this equals to the $3.26 \%$ of the total asset value. This could be used as a rule of thumb to plan the budget for the mid-size shipyards, as long as the proportion of infrastructure, equipment and tools be similar.

This value could also help to improve the pricing of the offered services considering a proper level of maintenance. For example, considering an annual revenue of this shipyard for $\$ 25 \mathrm{M}$ USD, the planned maintenance cost ( $\$ 238.000$ USD) is equal to the $0,95 \%$ of this revenue, and this percentage should be charged for every order made, with specific destination to maintenance.

Furthermore, a more detailed control on the life cycle costs for every machine and equipment, can lead to decide which processes and services are more profitable, and which don't, so is better to outsource.

\section{Conclusion}

The maintenance management is one of the core issues that any industrial factory must address. Its importance has no doubt about, and in the last years many formal education, new techniques, methods and technologies are available.

However, the cost maintenance estimation still is a matter that most organizations keep secret. From the manufacturer point of view, does not worth to disclose the studies about the required cost of maintenance while the competitors are not forced to. From the companies point of view, the optimal maintenance cost is a commercial secret that took many years to get, so it makes no sense to reveal it. All this issues are the same for the shipbuilding industry. However, in order to make an estimation of investment in new machinery, a relocation on the layout, or to evaluate the estimated profit for a new shipbuilding project, it is of great importance to know how much the maintenance of the facilities will cost. For this reason this research was conducted, in order to find a rule of thumb about what is the ordinary cost of maintenance of a midtier shipyard or similar industries composed by infraestructure (buildings) and machinery. Then would be a better understanding of how much the maintenance cost can be reduced keeping a good rate of operativity and security, in order to increase the overall profit.

\section{References}

[1] I. M. O. G. PALENCIA, "Tendencias actuales del mantenimiento industrial," Reportero industrial, April 2014. [Online]. Available: http://www.reporteroindustrial.com/temas/ Tendencias-actuales-en-mantenimientoindustrial+97221?pagina $=1$. [Accessed 09 August 2019].

[2] ACIEM, Diagnostico del mantenimiento en Colombia, Capitulo Cundinamarca ed., Bogota D.C., 2018. 
[3] L. F. C. PATIÑO, "Mantenimiento industrial: La columna vertebral de su empresa," in Aceros Antiabración: una batalla contra el desgaste, 2009, pp. 28-33.

[4] Arquitectos especializados del Noroeste, "Clasificación de los tipos de mantenimiento," Arquitectos especializados del Noroeste, [Online]. Available: https://aen.mx/ clasificacion-de-los-tipos-de-mantenimientoindustrial/. [Accessed 15 July 2019].

[5] D. LUNA, "Metalmecanica Internacional," December 2007. [Online]. Available: http://www.metalmecanica.com/temas/ Cuales-son-las-maquinas-y-tecnologiasque-estan-transformando-la-industriametalmecanica +122977 ?pagina $=1$.

[6] NASA, «Reliability-Centered Maintenance Guide,» September 2008. [On line]. Available: https://www.nasa.gov/sites/default/files/atoms/ files/nasa_rcmguide.pdf. [Último acceso: 20 January 2019].

[7] J. D. NAVARRO, Técnicas de Mantenimiento industrial, Calpe Institute of Technology, 2007.

[8] L. N. ELOLA, A. C. P. TEJEDOR AND J. M. M. LACABRERA, Gestión integral del Mantenimiento, Marcombo Boixareu, 1997.

[9] K. KOMONEN, "A cost model of industrial maintenance for profitability analysis and benchmarking," international journal production economics, 2000.

[10] F. J. G. FERNÁNDEZ, Teoría y práctica del mantenimiento industrial avanzado, 2 ed., FC editorial, 2011.

[11] J. L. GARCÍA, "Las cinco generaciones del mantenimiento," 21 February 2013. [Online]. Available: http:// gestionmantenimientoeficiente.blogspot. com/2013/02/las-cinco-generaciones-delmantenimiento.html. [Accessed 17 July 2019].
[12] J. GAMARRA, Tecnicas de mantenimiento industrial, 2013.

[13] B. VILA ARAICO, "Plataforma de mantenimiento basado en condición CBM de material rodante," El blog de innovación y tecnología de Altran España, 10 February 2016. [Online]. Available: https://blog.altran. es/industria-energia/mantenimiento-basadoen-condicion-cbm/. [Accessed 29 June 2019].

[14] MACHINE TOOLS WORLD, "ELGI: Costo de ciclo de vida para compresores," [Online]. Available: https://www.mtwmag.com/energyefficiency-compressors/elgi-lifecycle-cost-forcompressors/\#noopener\%20noreferrer/4/. [Accessed 24 July 2019].

[15]S.GARCIAGARRIDO,"ELPRESUPUESTO ANUAL DE MANTENIMIENTO," RENOVETEC, 2012. [Online]. [Accessed 9 July 2019].

[16] R. LOPEZ GUARANGO, "Instituto Tecnológico Superior "Carlos Cisneros"," 2015. [Online]. Available: https://es.slideshare.net/ jcaminos2/tesis-cepilladora-2015. [Accessed 8 June 2019].

[17] P. CERVERA, «Este caza es una ruina: los brutales costes de volar cada hora un avión de combate,» El confidencial, 9 May 2016. [On line]. Available: https://www.elconfidencial. com/tecnologia/2016-05-09/caza-avioncombate-costes-ruina_1196165/. [Último acceso: 12 July 2019].

[18] B. PROPFE, M. REDELBACH, D. J. SANTINI AND H. FRIEDRICH, "Cost analysis of Plug-in Hybrid Electric Vehicles including," Institute of Vehicle Concepts, German Aerospace Center (DLR), Los angeles, California, 2012.

[19] WIDMAN INTERNATIONAL SRL, "El Costo de Mantenimiento de Equipo Pesado," 6 October 2019. [Online]. Available: https:// www.widman.biz/mantenimiento/pesado.php. 
[20] M. R. BECERRA GUZMAN, Y. P. BOHORQUEZFARFANANDE.FAJARDO OSPINO, "Diseño e implementación de un programa de mantenimiento preventivo para la maquinaria de la Empresa Mejía Villegas Constructores S.A.," 2007. [Online]. Available: http://repositorio.unicartagena. edu.co/handle/11227/763. [Accessed 16 May 2019].

[21] FERROPEDIA, "Costos de mantenimiento de infraestructura," 2014. [Online].
[22] FERROPEDIA, "Ferropedia," 3 January 2017. [Online]. Available: http://www. ferropedia.es/mediawiki/index.php/Costos_ de_construcci\%C3\%B3n_de_infraestructura. [Accessed 22 June 2019].

[23] F. S. ALAA CHATEAUNEUF, "Maintenance Cost Models," 16 Jun 2014. [Online]. Available: https://hal.archives-ouvertes.fr/hal-01007484/ document. [Accessed 5 Jun 2019]. 